\title{
Development of an Automatic pH Adjustment Instrument for the Preparation of Analytical Samples Prior to Solid Phase Extraction
}

\author{
Yanbei ZhU, ${ }^{* \dagger}$ Sayaka Nishigori, ${ }^{* *}$ Nobuaki ShImura, ${ }^{* *}$ Tomio NARA, ${ }^{* *}$ and Eiji FuJIMORI*** \\ *National Metrology Institute of Japan (NMIJ), National Institute of Advanced Industrial Science and \\ Technology (AIST), 1-1-1 Umezono, Tsukuba, Ibaraki 305-8563, Japan \\ **System Instruments Co., Ltd., 776-2 Komiyamachi, Hachioji, Tokyo 192-0031, Japan \\ ***National Environmental Research and Training Institute, 3-3 Namiki, Tokorozawa, Saitama 359-0042, Japan
}

\begin{abstract}
An automatic $\mathrm{pH}$ adjustment instrument was developed for the preparation of analytical samples prior to solid phase extraction, which is widely used as a pretreatment technique for the separation of sample matrixes and preconcentration of elements for analysis. Real-time monitoring of the sample $\mathrm{pH}$ condition was performed by observing the light signal intensity of the $\mathrm{pH}$-sensitive wavelength of the $\mathrm{pH}$ indicating reagent. A light of $\mathrm{pH}$-insensitive wavelength was selected as the reference light to cancel the signal intensity variation of the $\mathrm{pH}$-sensitive light due to the difference of $\mathrm{pH}$ indicating reagent concentration, possible difference in transparency of sample vessels, and minute fluctuation of the light source. The $\mathrm{pH}$ condition was elevated by automatic addition of ammonia solution using a nebulizer in the flow line of which an electromagnetic valve was equipped. Open and close operation of the electromagnetic valve was controlled based on the difference between the real-time $\mathrm{pH}$ condition and the target $\mathrm{pH}$ condition. The effectiveness of the instrument was confirmed by using various $\mathrm{pH}$ indicating reagents and by analyzing trace elements in a seawater certified reference material.
\end{abstract}

Keywords Automatic $\mathrm{pH}$ adjustment instrument, solid phase extraction, $\mathrm{pH}$ indicating reagent, spectrometer, nebulization

(Received December 27, 2019; Accepted February 10, 2020; Advance Publication Released Online by J-STAGE February 21, 2020)

\section{Introduction}

Solid phase extraction (SPE) is an effective approach for the separation of sample matrix and the preconcentration of the analytes in chemical analysis. SPE techniques using chelating resins have been widely investigated as sample pretreatment methods for trace elements prior to their measurement. ${ }^{1-39}$ Due to the mechanism of SPE with chelating resin, i.e. adsorption of trace elements to the resin at weak acidic to neutral $\mathrm{pH}$ conditions and desorption from the resin in strong acidic conditions, the optimum $\mathrm{pH}$ conditions reported for adsorption were usually $5,{ }^{1-8} 5.5,{ }^{9-14} 5.7,,^{15} 6,{ }^{16-27} 6.13,{ }^{28} 6.5,{ }^{29,30}$ and $7 . .^{31-33}$ There have also been several works reporting multiple $\mathrm{pH}$ conditions, e.g. $4.0-7.0,{ }^{34} 5.0$ and $6.0,{ }^{35} 5.5,6.5$, and 8.5, ${ }^{36} 6,7$, and $8,{ }^{37} 6.0-7.0,{ }^{38}$ and $6.0-7.5 .{ }^{39}$ Such optimum conditions depend on the chemical property of the target element and the sample matrix as well as the functional group and the chemical structure of the chelating resin. Nevertheless, the optimum $\mathrm{pH}$ conditions were most often chosen in the $\mathrm{pH}$ range from 5.0 to 7.0 as indicated by the aforementioned reports.

The precise adjustment of a solution to neutral $\mathrm{pH}$ condition requires the precise controlling of $\mathrm{H}^{+}$concentration at the $10^{-6}$ to $10^{-7} \mathrm{~mol} \mathrm{~L}^{-1}$ level. Therefore, great attention should be paid for manual adjustment of $\mathrm{pH}$ for SPE with chelating resins. A commercially available preconcentration system, i.e. seaFAST

† To whom correspondence should be addressed.

E-mail: yb-zhu@aist.go.jp
(Elemental Scientific), provids an approach for $\mathrm{pH}$ adjustment by diluting the sample with an ammonium acetate buffer. ${ }^{40-45}$ Due to the limited naturalization capability of ammonium acetate buffer, the samples after $\mathrm{pH}$ adjustment usually had high concentrations of ammonium ions and acetate ions. They may compete with the cations of trace elements and the functional groups of the chelating resin, respectively, during the SPE operations. Apparent lower recoveries for some elements reported might be attributed to the competition with such cations and anions. ${ }^{41,44,45}$

As an alternative approach for precise $\mathrm{pH}$ adjustment in SPE operations with chelating resin, the authors developed an automatic $\mathrm{pH}$ adjustment instrument and applied it to the measurement of rare earth elements (REEs) in seawater samples. ${ }^{46}$ In the automatic $\mathrm{pH}$ adjustment instrument, the $\mathrm{pH}$ of a sample solution with $\mathrm{pH}$ indicating reagent (methyl-red) was monitored by measuring the transmitted light, based on a pre-established correlation between the $\mathrm{pH}$ and the transmitted light-intensity. Such non-contact monitoring of the $\mathrm{pH}$ condition of the sample avoided possible contamination from a $\mathrm{pH}$ electrode. The addition of ammonia solution for elevating the $\mathrm{pH}$ from acidic to neutral condition was precisely controlled by a nebulizer (usually used in inductively coupled plasma techniques) and an electro-magnetic valve, permitting a precise addition of ammonia solution at less than $0.1 \mu \mathrm{L}$. Real-time monitoring of the $\mathrm{pH}$ condition based on transmitted light and precise controlling of ammonia solution permitted the precise $\mathrm{pH}$ adjustment for SPE operations with chelating resins. The instrument was applied to the analysis of REEs in seawater 
samples. However, it was found later that the transmitted light based $\mathrm{pH}$ monitoring required high reproducibility of the container light-transparency as well as a precise concentration of $\mathrm{pH}$ indicating reagent in the sample.

In the present work, the automatic $\mathrm{pH}$ adjustment instrument was improved to achieve a precise $\mathrm{pH}$ adjustment independent of the concentration of $\mathrm{pH}$ indicating reagent in the sample solution. An application of the present automatic $\mathrm{pH}$ adjustment instrument had been preliminary reported and referred to as "electrodeless $\mathrm{pH}$ controller". ${ }^{47}$ Technical details about the automatic $\mathrm{pH}$ adjustment instrument are presented in the present work along with the application to the determination of multiple trace elements in a seawater certified reference material (CRM).

\section{Experimental}

\section{Instruments}

An ICP-MS instrument (Agilent 8800s type) was applied for the analysis of trace elements. The operating conditions of the ICP-MS were optimized daily to achieve relatively high signal intensities for the elements of interest. Typical operating conditions of the ICP-MS can be found in Supporting Information (Table S1). Hydrogen gas was used as the reaction gas for effective removal of polyatomic interferences, e.g. ${ }^{40} \mathrm{Ar}^{16} \mathrm{O}^{+}$with the measurement of ${ }^{56} \mathrm{Fe}^{+}$, and ${ }^{94} \mathrm{Mo}^{16} \mathrm{O}^{+}$with the measurement of ${ }^{110} \mathrm{Cd}^{+}$.

\section{Reagents and chemicals}

Metrological traceable single element standard solutions were purchased from Kanto Chemical Co., Inc. (Tokyo, Japan). The traceability of the standard solutions were guaranteed by the Japan Calibration Service System (JCSS). Ultrapur ${ }^{\circledR} \mathrm{HNO}_{3}$, ammonia solution, acetic acid and reagent grade ethanol were also purchased from Kanto Chemical Co., Inc., and used for preparing the solutions in the present experiment. Reagent grade bromophenol-blue, bromocresol-green, methyl-red, and phenol-red were also purchased from Kanto Chemical Co. Inc. to prepare solutions of $\mathrm{pH}$ indicating reagents.

A seawater CRM was purchased from the National Research Council of Canada. Chelating resin columns, NOBIAS ChelatePA1 (M-size), were purchased from Hitachi High-Tech Fielding Corp. (Tokyo, Japan).

\section{Construction of the automatic adjustment instrument}

The structure of the automatic $\mathrm{pH}$ adjustment instrument is illustrated in Fig. 1. As can be seen from Fig. 1, the light from light source (1) transmitted through the sample (2), which was mixed with a magnetic rotor (3) driven by a magnetic stirrer (4) at 100 revolutions per minute. The transmitted light was measured by a spectrometer (5), which sent a signal to the I/O board (6) and then to the controlling computer (7). Based on the correlation between the signal intensity ratio of a $\mathrm{pH}$ sensitive light to a $\mathrm{pH}$-insensitive light and the $\mathrm{pH}$ condition, the controlling computer sent open/close commands to the $\mathrm{I} / \mathrm{O}$ board (6) and then to the electro-magnetic valve (8). The open/ close operation of the electro-magnetic valve (8) controlled the supply of ammonia solution (9) through the nebulizer (10) to the sample solution (2), where the addition of ammonia solution (2) through the nebulizer (10) was driven by the air (11) with a flow rate of approximately $1.0 \mathrm{~L} \mathrm{~min}^{-1}$ and resulting in an uptake rate of ammonia solution at $0.5 \mathrm{~mL} \mathrm{~min}{ }^{-1}$, where an in-line filter was equipped to prevent contamination from the atmosphere.

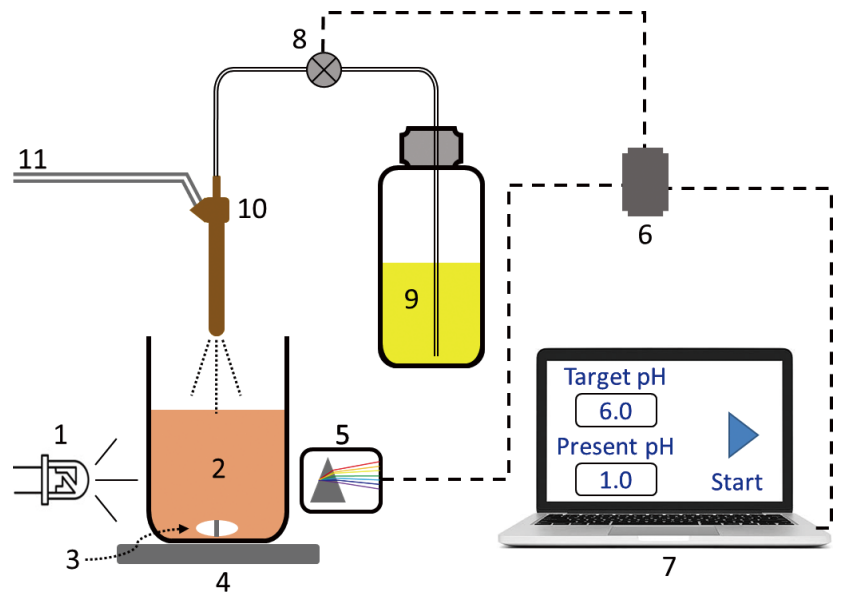

Fig. 1 Structure of the automatic $\mathrm{pH}$ adjustment instrument. 1, Light source; 2 , sample; 3 , rotor; 4, magnetic stirrer; 5, spectrometer; 6 , IO board; 7, computer; 8 , electro-magnetic valve; 9, ammonia solution; 10 , nebulizer; 11 , air.

\section{Flow chart for the automatic controlling program}

The typical operation of the automatic controlling program for the instrument is illustrated with a flow chart in Fig. 2. As can be seen from Fig. 2, the valve was closed and the target $\mathrm{pH}$ value $\left(A_{\mathrm{t}}\right)$ was read after starting the adjustment. The signal intensities of $\mathrm{pH}$-sensitive light $\left({ }^{\mathrm{a}} I_{\mathrm{i}}\right)$ and $\mathrm{pH}$-insensitive light $\left({ }^{\mathrm{r}} I_{\mathrm{i}}\right)$ were read from the spectrometer. Then, the current $\mathrm{pH}$ value $\left(A_{\mathrm{i}}\right)$ was calculated from the signal intensity ratio of $\left({ }^{\mathrm{a}} \mathrm{I}_{\mathrm{i}} / \mathrm{I}_{\mathrm{i}}\right)$. The difference between the values of $A_{\mathrm{i}}$ and $A_{\mathrm{t}}$ was calculated as $\Delta A$, which was compared with 0.0 so as to evaluate whether the target $\mathrm{pH}$ was achieved. It is notable that water samples for trace elements analysis are usually stored at relatively strong acidic conditions with $\mathrm{pH}$ lower than 1.0. The purpose for adjustment of $\mathrm{pH}$ condition for SPE operation is usually to elevate the $\mathrm{pH}$ value, i.e. " $A_{\mathrm{i}}<A_{\mathrm{t}}$ " in the beginning of the $\mathrm{pH}$ adjustment.

When the target $\mathrm{pH}$ was not achieved, i.e. " $\Delta A=0.0$ " was not satisfied, the value of $\Delta A$ was further compared with $0.6,0.4$, $0.3,0.2$, and 0.1 in turn. When the value of $\Delta A$ was over 0.6 , the valve was kept open, permitting introduction of ammonia solution into the sample to elevate the $\mathrm{pH}$ value until the next round of calculations of $A_{\mathrm{i}}$ and evaluation of whether " $\triangle A=$ 0.0 ". When the condition of " $0.6>=\Delta A>0.4$ ", " $0.4>=\Delta A$ $>0.3$ ", "0.3> $=\Delta A>0.2$ ", "0.2>= $\Delta A>0.1$ ", and " $0.1>=$ $\Delta A>0.0$ " was respectively satisfied, the valve open/close times (unit, ms) were respectively set to 3000/2000, 2000/2000, $1000 / 1500,500 / 2000$, and $150 / 2500$ until the next round of calculations of $A_{\mathrm{i}}$ and evaluation of whether " $\Delta A=0.0$ ". The open/close time sets were optimized to permit the sample to become completely mixed after each round of ammonia solution addition, as well as to avoid over addition of ammonia solution. When the target $\mathrm{pH}$ was achieved, i.e. " $\Delta A=0.0$ " was satisfied, the valve was closed and the program of $\mathrm{pH}$ adjustment ended.

\section{Procedure for SPE preconcentration with chelating resin}

The typical procedure for SPE preconcentration with chelating resin used in the present work was as follows. The chelating resin columns (NOBIAS CHELATE-PA1) were washed with $5 \mathrm{~mL}$ of $3 \mathrm{~mol} \mathrm{~L}^{-1}$ nitric acid and $5 \mathrm{~mL}$ of pure water, followed by conditioning with $5 \mathrm{~mL}$ of $0.1 \mathrm{~mol} \mathrm{~L}^{-1}$ ammonia acetate. Then, $50 \mathrm{~mL}$ of the sample (with $100 \mu \mathrm{L}$ of $0.4 \mathrm{mg} \mathrm{mL}^{-1}$ 


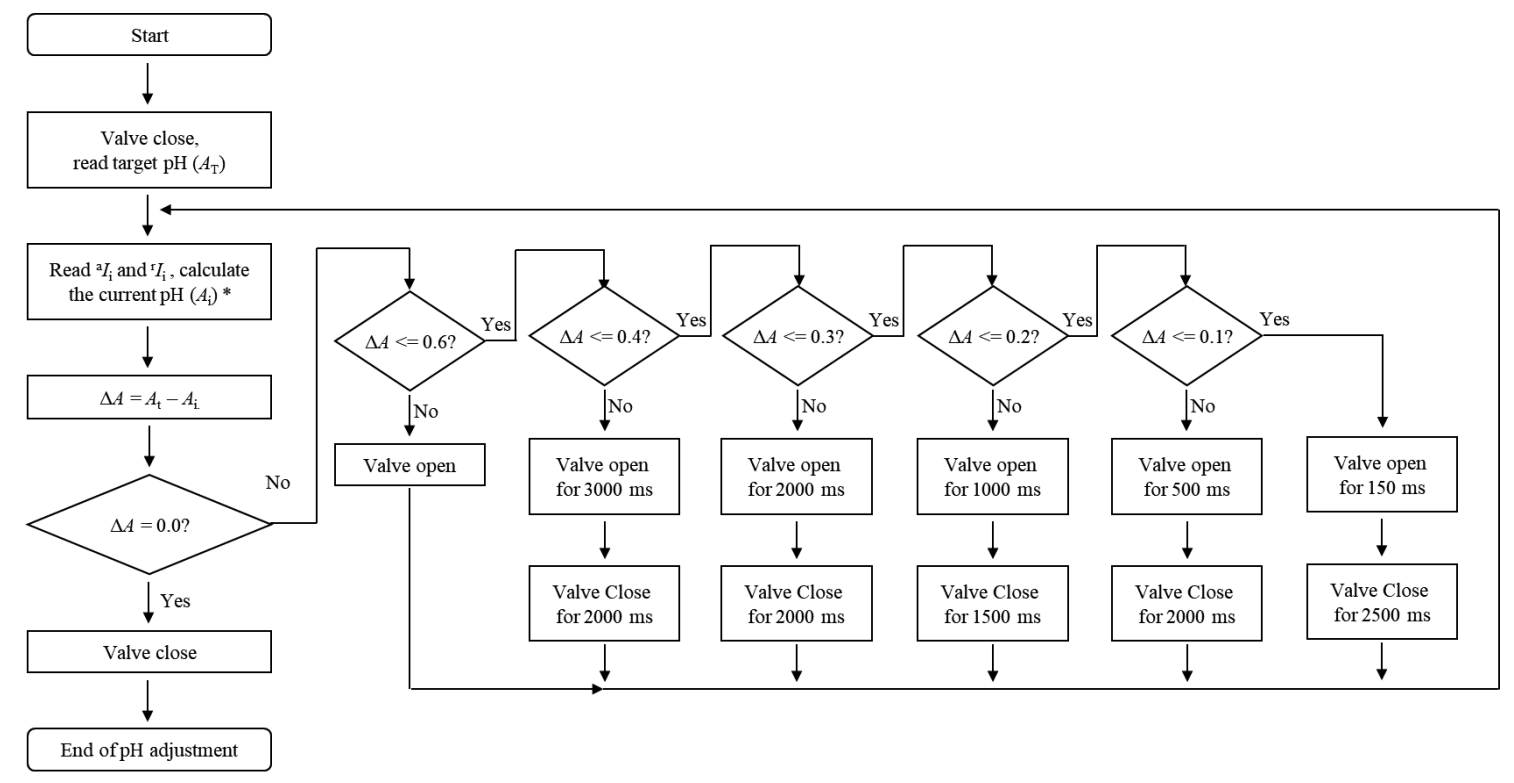

Fig. 2 Flow-chart for automatic pH adjustment. *, ${ }^{\mathrm{a}} \mathrm{I}_{\mathrm{i}}$ and ${ }^{\mathrm{r}} \mathrm{I}_{\mathrm{i}}$, indicate signal intensities of the $\mathrm{pH}$-sensitive light and the $\mathrm{pH}$-insensitive light, respectively.

methyl-red in ethanol as $\mathrm{pH}$ indicating reagent) adjusted to $\mathrm{pH} 6.0$ was loaded to the chelating resin column at a flow rate of approximately $10 \mathrm{~mL} \mathrm{~min}{ }^{-1}$. After sample loading, $10 \mathrm{~mL}$ of $0.1 \mathrm{~mol} \mathrm{~L}^{-1}$ ammonia acetate and $5 \mathrm{~mL}$ of pure water were passed through the chelating resin column for washing. Finally, trace elements adsorbed on the resin was eluted with $5 \mathrm{~mL}$ of $2 \mathrm{~mol} \mathrm{~L}^{-1}$ nitric acid and then subjected to the measurement by ICP-MS.

The samples for blank test and recovery test were also subjected to the same procedure for SPE preconcentration.

Quantitation of trace elements was carried out based on a gravimetric-based standard addition method following the procedure described in a previously reported work. ${ }^{48}$ An yttrium standard solution was spiked to each sample in the present work to achieve a concentration of $1 \mathrm{ng} \mathrm{mL}^{-1}$ yttrium in the sample solution prior to $\mathrm{pH}$ adjustment. The signal of ${ }^{89} \mathrm{Y}^{+}$was measured as the internal standard.

\section{Results and Discussion}

Effectiveness of a reference light for ensuring the stability of $\mathrm{pH}$ adjustment

In the present work, a light of $\mathrm{pH}$-insensitive wavelength was used as the reference light to cancel the variation of brightness of the sample solution, probably due to the minute variations in the concentration of $\mathrm{pH}$ indicating reagent and the transparency of sample vessels.

The effectiveness of a reference light for ensuring the stability of $\mathrm{pH}$ adjustment was confirmed by using methyl-red as the $\mathrm{pH}$ indicating reagent and by setting the target $\mathrm{pH}$ value to 6.0 . Based on the absorption properties of methyl-red as a $\mathrm{pH}$ indicating reagent shown in Fig. 3, the $\mathrm{pH}$-sensitive wavelength and the $\mathrm{pH}$-insensitive wavelength were chosen at 530 and $620 \mathrm{~nm}$, respectively.

The calibrating curve for calculating the $\mathrm{pH}$ value from the signal intensities at the $\mathrm{pH}$-sensitive wavelength and the $\mathrm{pH}$-insensitive wavelength were obtained by addition of $100 \mu \mathrm{L}$ methyl-red $\left(0.4 \mathrm{mg} \mathrm{mL}^{-1}\right.$ in ethanol) to each $50 \mathrm{~mL}$ of coastal

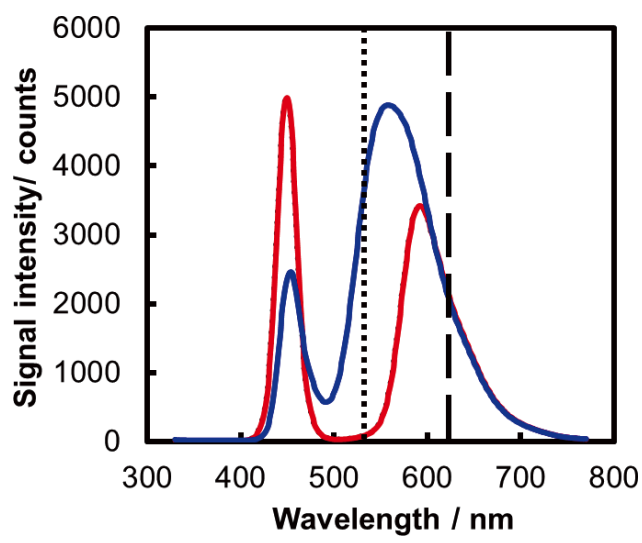

Fig. 3 Absorption properties of methyl-red as a $\mathrm{pH}$ indicating reagent. Red line profile, $\mathrm{pH} 1.0$; blue line profile, $\mathrm{pH} 8.0$; dotted line, $\mathrm{pH}$-sensitive wavelength; dashed line, $\mathrm{pH}$-insensitive wavelength. Obtained with a 50-mL coastal seawater sample with $100 \mu \mathrm{L}$ methylred $\left(0.4 \mathrm{mg} \mathrm{mL}^{-1}\right.$ in ethanol).

seawater sample. After that, test samples ( $50 \mathrm{~mL}$ each) with 80 , 100 , and $120 \mu \mathrm{L}$ of methyl-red were respectively prepared and subjected to the automatic $\mathrm{pH}$ adjustment. The relative difference in signal intensity of $\mathrm{pH}$-sensitive wavelength at $530 \mathrm{~nm}$ in these samples was over $30 \%$. After $\mathrm{pH}$ adjustment with the present automatic instrument, the $\mathrm{pH}$ values in these samples were all in the range of 5.98 to 6.00 , which were sufficiently precise for SPE operations with chelating resins. When the reference light was not used, the difference in volume of methyl-red by $40 \mu \mathrm{L}$ may result in the difference of $\mathrm{pH}$ value of approximately 0.3 to 0.5 . These results indicate that use of a reference light was effective for ensuring the stability of $\mathrm{pH}$ adjustment. Therefore, a reference light was also used for $\mathrm{pH}$ adjustment with other $\mathrm{pH}$ indicating reagents. 
Table 1 Typical $\mathrm{pH}$ indicating reagents confirmed in the present work ${ }^{\mathrm{a}}$

\begin{tabular}{|c|c|c|c|c|c|c|}
\hline $\begin{array}{l}\mathrm{pH} \text { indicating } \\
\text { reagent }\end{array}$ & $\begin{array}{l}\mathrm{pH} \text { range } \\
\text { and color }\end{array}$ & $\begin{array}{l}\text { Concentration } \\
\text { and solvent }\end{array}$ & $\begin{array}{c}\text { Volume added } \\
(\mu \mathrm{L} \text { per } 50 \mathrm{~mL} \text { sample })\end{array}$ & $\begin{array}{c}\mathrm{pH} \text {-sensitive } \\
\text { wavelength/nm }\end{array}$ & $\begin{array}{l}\mathrm{pH} \text {-insensitive } \\
\text { wavelength/nm }\end{array}$ & $\begin{array}{l}\text { Target } \mathrm{pH} \\
\text { range }\end{array}$ \\
\hline Bromophenol-blue & $\begin{array}{l}\text { pH } 3.0-4.6 \\
\text { (yellow } \leftrightarrow \text { purple) }\end{array}$ & $\begin{array}{l}0.4 \mathrm{mg} \mathrm{mL}^{-1} \text { in } \\
\text { ammonia solution }\end{array}$ & 100 & 571 & 650 & 3.0 to 4.0 \\
\hline Bromocresol-green & $\begin{array}{l}\mathrm{pH} 3.8-5.4 \\
\text { (yellow } \leftrightarrow \text { blue) }\end{array}$ & $\begin{array}{l}0.4 \mathrm{mg} \mathrm{mL}^{-1} \text { in } \\
\text { ammonia solution }\end{array}$ & 100 & 573 & 507 & 4.0 to 5.0 \\
\hline Methyl-red & $\begin{array}{l}\mathrm{pH} 4.4-6.2 \\
\text { (red } \leftrightarrow \text { yellow) }\end{array}$ & $\begin{array}{l}0.4 \mathrm{mg} \mathrm{mL}^{-1} \text { in } \\
\text { ethanol }\end{array}$ & 100 & 530 & 620 & 5.0 to 6.0 \\
\hline Phenol-red & $\begin{array}{l}\mathrm{pH} 6.4-8.2 \\
\quad \text { (yellow } \leftrightarrow \text { red) }\end{array}$ & $\begin{array}{l}0.4 \mathrm{mg} \mathrm{mL}^{-1} \text { in } \\
\text { ammonia solution }\end{array}$ & 100 & 560 & 610 & 6.0 to 8.0 \\
\hline
\end{tabular}

a. Typical calibration curves for these $\mathrm{pH}$ indicating reagents are provided as Supporting Information (Figs. S1 to S4).

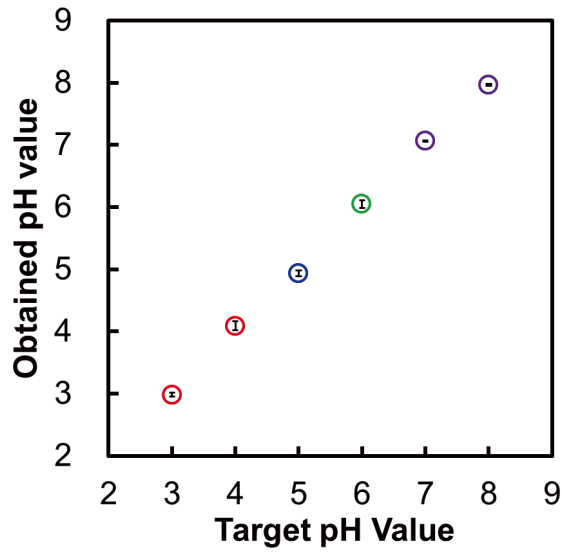

Fig. 4 Results of automatic $\mathrm{pH}$ adjustment. ( $\mathrm{pH}$ indicating reagents: red circle, bromophenol-blue; blue circle, bromocresol-green; green circle, methyl-red; purple circle, phenol-red; bar in the circle, standard deviation of 3 sub-samples.)

Typical $\mathrm{pH}$ indicating reagents and applicable $\mathrm{pH}$ range with the present instrument

Multiple $\mathrm{pH}$ indicating reagents were investigated in the present work to ensure the possibility of automatic and precise $\mathrm{pH}$ adjustment in a relatively wide $\mathrm{pH}$ range from 3.0 to 8.0. The characteristics of four $\mathrm{pH}$ indicating reagents are summarized in Table 1.

The $\mathrm{pH}$ indicating reagents were dissolved in ammonia solution (bromophenol-blue, bromocresol-green, and phenol-red) or ethanol (methyl-red), to obtain a concentration of $0.4 \mathrm{mg} \mathrm{mL}^{-1}$. Typically, $100 \mu \mathrm{L}$ of the $\mathrm{pH}$ indicating reagent solution was added into each $50 \mathrm{~mL}$ of water sample for $\mathrm{pH}$ monitoring. As summarized in Table 1, the characteristic lights (unit, $\mathrm{nm}$ ) of the $\mathrm{pH}$-sensitive and the $\mathrm{pH}$-insensitive wavelengths for bromophenol-blue, bromocresol-green, methyl-red, and phenolred were 580/650,570/515,530/620, and 560/610, respectively.

Application of the $\mathrm{pH}$ indicating reagents permitted the coverage of a target $\mathrm{pH}$ range from 3.0 to 8.0 by the present automatic $\mathrm{pH}$ adjustment instrument. The results of automatic $\mathrm{pH}$ adjustment to 3.0 to 8.0 are plotted in Fig. 4 against the target $\mathrm{pH}$ value assigned. As can be seen from Fig. 4 , the obtained $\mathrm{pH}$ values were identical to the target values. The results show that the present instrument was capable for accurate and precise $\mathrm{pH}$ adjustment.

\section{Analytical figures of merits}

Blank values and analytical detection limits (ADLs) were
Table 2 Blank values and ADLs obtained with ICP-MS after SPE preconcentration

\begin{tabular}{cccl}
\hline Element & $m / z$ & Blank value $/ \mathrm{ng} \mathrm{mL}^{-1}$ & $\mathrm{ADL}^{\mathrm{b}} / \mathrm{ng} \mathrm{mL}^{-1}$ \\
\hline $\mathrm{Fe}$ & 56 & $0.11 \pm 0.05$ & 0.14 \\
$\mathrm{Co}$ & 59 & $0.00019 \pm 0.00008$ & 0.00025 \\
$\mathrm{Ni}$ & 60 & $0.0035 \pm 0.0009$ & 0.0026 \\
$\mathrm{Cu}$ & 63 & $0.022 \pm 0.006$ & 0.0017 \\
$\mathrm{Zn}$ & 66 & $0.087 \pm 0.018$ & 0.053 \\
$\mathrm{Cd}$ & 110 & $0.00045 \pm 0.00014$ & 0.00043 \\
$\mathrm{~Pb}$ & 208 & $0.0021 \pm 0.0008$ & 0.0023 \\
\hline
\end{tabular}

a. Mean \pm standard deviation, $n=5$.

b. Concentration corresponding to 3 -fold of the standard deviation of blank value.

evaluated as the analytical figures of merits for trace elements obtained by ICP-MS after SPE preconcentration with chelating resin and with the present automatic $\mathrm{pH}$ adjustment instrument for sample preparation.

Blank values were obtained with $50 \mathrm{~mL}$ of $0.1 \mathrm{~mol} \mathrm{~L}^{-1}$ nitric acid as test samples. The test samples were subjected to the automatic $\mathrm{pH}$ adjustment and SPE preconcentration with chelating resin in the same way as that for the seawater samples, in which the concentration of nitric acid was also $0.1 \mathrm{~mol} \mathrm{~L}^{-1}$. The final solution for analysis after SPE preconcentration was $5 \mathrm{~mL}$, providing a preconcentration factor of 10 -fold. The results for blank tests are summarized in Table 2, along with ADLs obtained as the concentrations corresponding to 3-fold of the standard deviation of blank values.

As can be seen from Table 2, the blank values for trace elements were in the range from $0.00019 \mathrm{ng} \mathrm{mL}^{-1}$ of Co to $0.11 \mathrm{ng} \mathrm{mL}^{-1}$ of $\mathrm{Fe}$, while the ADLs were in the range from $0.00025 \mathrm{ng} \mathrm{mL}^{-1}$ of Co to $0.14 \mathrm{ng} \mathrm{mL}^{-1}$ of Fe. These values were sufficiently low for the analysis of water samples taking into consideration the regulated concentrations for these trace elements were not lower than $3 \mathrm{ng} \mathrm{mL}^{-1}{ }^{49}$ A preliminary experiment in the present work showed that the major factor contributing to the blank values was the impurities in the solid phase of the chelating resin, while the contribution of $\mathrm{pH}$ adjustment was negligible.

The typical time required for $\mathrm{pH}$ adjustment of $50 \mathrm{~mL}$ of these samples was approximately $15 \mathrm{~min}$. The time for automatic $\mathrm{pH}$ adjustment could be shorten to less than $5 \mathrm{~min}$ by partial neutralization of nitric acid in the sample, i.e. addition of some ammonia solution prior to the automatic $\mathrm{pH}$ adjustment.

The present instrument provided an approach for rapid and automatic $\mathrm{pH}$ adjustment independent to the skill of the operator. 
Table 3 Analytical results and recoveries of trace elements in seawater CRM, NRC CRM CASS-5

\begin{tabular}{ccccr}
\hline Element & $m / z$ & $\begin{array}{c}\text { Observed value } \\
\text { ng } \mathrm{mL}^{-1}\end{array}$ & $\begin{array}{c}\text { Certified value } \\
\text { ng mL }\end{array}$ & \multicolumn{1}{c}{$\begin{array}{c}\text { Spike } \\
\text { recovery }\end{array}$} \\
\hline $\mathrm{Fe}$ & 56 & $1.35 \pm 0.15$ & $1.44 \pm 0.11$ & $98.8 \pm 1.5$ \\
$\mathrm{Co}$ & 59 & $0.093 \pm 0.005$ & $0.095^{\mathrm{c}}$ & $97.3 \pm 1.8$ \\
$\mathrm{Ni}$ & 60 & $0.351 \pm 0.032$ & $0.330 \pm 0.023$ & $98.7 \pm 1.3$ \\
$\mathrm{Cu}$ & 63 & $0.375 \pm 0.021$ & $0.380 \pm 0.028$ & $100.2 \pm 0.8$ \\
$\mathrm{Zn}$ & 66 & $0.75 \pm 0.05$ & $0.719 \pm 0.068$ & $101.3 \pm 1.5$ \\
$\mathrm{Cd}$ & 110 & $0.0221 \pm 0.0005$ & $0.0215 \pm 0.0018$ & $100.4 \pm 1.4$ \\
$\mathrm{~Pb}$ & 208 & $0.013 \pm 0.003$ & $0.011 \pm 0.002$ & $98.7 \pm 1.2$ \\
\hline
\end{tabular}

a. Mean \pm standard deviation, $n=4$.

b. Mean \pm expanded uncertainty.

c. Information value.

Manual adjustment of a sample to $\mathrm{pH} 6.0$ depended on the skill of the operator, probably taking $30 \mathrm{~min}$ or even over $60 \mathrm{~min}$ to achieve a $\mathrm{pH}$ value in the range of 5.9 to 6.1 .

\section{Analytical results for trace elements in a seawater CRM}

Trace elements in a seawater CRM, NCR CRM CASS-5, were analyzed to confirm the reliability of the present automatic $\mathrm{pH}$ adjustment instrument and the present analytical method. The analytical results, after subtracting the blank values given in Table 2, are summarized in Table 3 in comparison to the certified values.

As can be seen in Table 3, the observed values agreed with the certified values in the range of their expanded uncertainties. It is notable that the concentrations of these elements were at least one order of magnitude higher than the blank values and the ADLs given in Table 2, permitting accurate and precise analysis of these elements.

The spike recovery values given in Table 3 were obtained by adding a mixture of elemental standard solution so as to achieve a spiking concentration of $2 \mathrm{ng} \mathrm{mL}^{-1}$ for each element in the spiked seawater CRM sample. It can be seen from Table 3 that the recovery values were quite close to $100 \%$ with good reproducibility, i.e. standard deviation less than $2 \%$.

These results indicate that the present automatic $\mathrm{pH}$ adjustment instrument and the present analytical method are effective for the analysis of trace elements in environmental samples including seawater.

\section{Conclusions}

An automatic $\mathrm{pH}$ adjustment instrument was developed for SPE preconcentration of trace elements with chelating resin. The automatic and real-time monitoring of the sample $\mathrm{pH}$ condition was obtained by monitoring the light signal intensity of the $\mathrm{pH}$ sensitive wavelength for the $\mathrm{pH}$ indicating reagent. Stable $\mathrm{pH}$ monitoring was improved by using a reference light at the $\mathrm{pH}-$ insensitive wavelength for the $\mathrm{pH}$ indicating reagent. Automatic and precise addition of ammonia solution to the sample to elevate the $\mathrm{pH}$ condition to the target value was achieved by using a nebulizer, for which the flow line was controlled with an electromagnetic valve. Open and close operation of the electromagnetic valve was controlled based on the difference between the real-time $\mathrm{pH}$ value and the target $\mathrm{pH}$ value. The results of trace elements in NRC CRM CASS-5 indicate that the present instrument was effective for automatic $\mathrm{pH}$ adjustment for SPE preconcentration with chelating resin.

\section{Supporting Information}

Table S1, operating conditions for ICP-MS. Figures S1 to S4, typical calibration curves for $\mathrm{pH}$ adjustment using different $\mathrm{pH}$ indicating reagents.

\section{References}

1. W.-J. Li, C. Tai, and X.-X. Gu, Int. J. Environ. Anal. Chem., 2001, 81, 127.

2. E. Vassileva and N. Furuta, Spectrochim. Acta, Part B, 2003, 58, 1541.

3. Y.-W. Liu, X.-J. Chang, Y. Guo, B.-J. Ding, and S.-M. Meng, Solv. Extr. Ion Exch., 2005, 23, 725.

4. A. Tsuneto, Y. Suzuki, Y. Furusho, and N. Furuta, Bunseki Kagaku, 2009, 58, 623.

5. M. Ghaedi, H. Tavallali, M. Montazerozohori, E. Zahedi, M. Amirineko, S. Khodadoust, and G. Karimipour, Environ. Monit. Assess., 2012, 184, 6583.

6. K. Kocot and R. Sitko, Spectrochim. Acta, Part B, 2014, 94-95, 7.

7. R. Saxena, N. Sharma, and S. Tiwari, Anal. Sci., 2015, 31, 1303.

8. K. Hagiwara, S. Kai, Y. Koike, M. Aizawa, and T. Nakamura, Bunseki Kagaku, 2016, 65, 489.

9. T. Sumida, T. Nakazato, and H. Tao, Bunseki Kagaku, 2003, 52, 619.

10. Y.-S. Kim, G. In, C.-W. Han, and J.-M. Choi, Microchem. J., 2005, 80, 151.

11. H. Sakamoto, K. Yamamoto, T. Shirasaki, and Y. Inoue, Bunseki Kagaku, 2006, 55, 133.

12. T. Sumida, T. Nakazato, H. Tao, M. Oshima, and S. Motomizu, Anal. Sci., 2006, 22, 1163.

13. F. Zereen, V. Yilmaz, and Z. Arslan, Anal. Lett., 2014, 47, 58.

14. S. Kagaya, T. Katoh, M. Saito, M. Ohki, R. Shirota, Y. Saeki, T. Kajiwara, S. Nakada, H. Miyazaki, M. GemmeiIde, and Y. Inoue, Talanta, 2018, 188, 665.

15. H. Takata, K. Tagami, T. Aono, and S. Uchida, At. Spectrosc., 2009, 30, 10.

16. T. Yabutani, S. Ji, F. Mouri, H. Sawatari, A. Itoh, K. Chiba, and H. Haraguchi, Bull. Chem. Soc. Jpn., 1999, 72, 2253.

17. V. A. Lemos, P.-X. Baliza, R. T. Yamaki, M. E. Rocha, and A. P. O. Alves, Talanta, 2003, 61, 675.

18. K.-H. Lee, Y. Muraoka, M. Oshima, and S. Motomizu, Anal. Sci., 2004, 20, 183.

19. Y. Zhu, A. Itoh, and H. Haraguchi, Bull. Chem. Soc. Jpn., 2005, 78, 107.

20. S. Kartal, I. Ozdemir, S. Tokalioglu, and V. Yilmazz, Sep. Sci. Technol., 2007, 42, 3199.

21. S. Ayata and M. Merdivan, J. Radianal. Nucl. Chem., 2010, 283, 603.

22. E. Moniri, H. A. Nanahi, M. Karimi, N. A. Rajabi, M. Faridi, and M. Manoochehri, Korean J. Chem. Eng., 2011, 28, 1523.

23. H. B. Sadeghi, H. A. Panahi, M. Abdouss, B. Esmaiilpour, M. N. Nezhati, E. Moniri, and Z. Azizi, J. Appl. Polym. Sci., 2013, 128, 1125.

24. N. Jalbani, R. M. Alosmanov, and M. Soylak, At. Spectrosc., 2014, 35, 163.

25. M. Soylak and A. Temeltas, Int. J. Environ. Anal. Chem., 2016, 96, 862.

26. Y.-S. Zheng, X.-L. Huang, Y.-H. Ling, W.-H. Huang, 
J.-X. Wang, Z.-X. Zheng, X.-D. Wang, and H.-L. Wang, Spectrochim. Acta, Part B, 2019, 157, 27.

27. Z. Erbas, R. Maulana, E. Yilmaz, S. Ozdemir, E. Kilinc, and M. Soylak, Int. J. Environ. Anal. Chem., 2019, DOI: 10.1080/03067319.2019.1646737.

28. H. Sereshti and M. Karimi, J. Iranian Chem. Soc., 2014, $11,1129$.

29. S-T. Chen, Y.-S. Yan, W.-Z. Xu, H. Liu, J.-J. Jing, and J.-M. Xie, Spectrosc. Spectral. Anal., 2007, 27, 1018.

30. H. A. Panahi, M. Rabbani, N. Zabarjad-Shiraz, S. Mofavvaz, E. Moniri, S. Kaghari, M. Entezari, and A. Hasanzadeh, Desalin. Water Treat., 2010, 22, 330.

31. A. Beiraghi, S. Babaee, and M. Roshdi, Microchem. J., 2012, 100, 66 .

32. A. N. Siyal, L. Elci, S. Q. Memon, A. Akdogan, A. Hol, A. A. Kartal, and M. Y. Khuhawar, Int. J. Environ. Anal. Chem., 2014, 94, 743.

33. O. F. Olorundare, T. A. M. Msagati, R. W. M. Krause, J. O. Okankwo, and B. B. Mamba, Int. J. Environ. Sci. Technol., 2015, 12, 2389.

34. S. Sonmez, U. Divrikli, and L. Elci, Talanta, 2010, 82, 939.

35. V. Yilmaz, A. Arslan, O. Hazer, and H. Yilmaz, Microchem. J., 2014, 114, 65.

36. A. R. Feizbakhash, H. A. Panahi, M. N. Nezhati, M. Amrollahi, and F. Mahmoudi, Water Environ. Res., 2009, 81, 532.

37. S. Meesri, N. Praphairaksit, and A. Imyim, Microchem. J., 2007, 87, 47.

38. V. K. Jain, R. A. Pandya, S. G. Pillai, and P. S. Shrivastav,
Talanta, 2006, 70, 257.

39. E. Moniri, H. A. Panahi, K. Aghdam, and A. A. M. Sharif, J. AOAC Int., 2015, 98, 206.

40. S. Poehle, K. Schmidt, and A. Koschinsky, Deep Sea Res., Part I, 2015, 98, 83.

41. I. Rapp, C. Schlosser, D. Rusiecka, M. Gledhill, and E. P. Achterberg, Anal. Chim. Acta, 2017, 976, 1.

42. S. L. Jackson, J. Spence, D. J. Janseen, A. R. S. Ross, and J. T. Cullen, J. Anal. At. Spectrom., 2018, 33, 304.

43. E. Vassileva, I. Wysocka, A. M. Orani, and C. Quetel, Spectrochim. Acta, Part B, 2019, 153, 19.

44. J. E. Strivens, J. M. Brandenberger, and R. K. Johnston, Limnol. Oceanogr:: Methods, 2019, 17, 266.

45. K. Wuttig, A. T. Townsend, P. van der Merwe, M. GaultRingold, T. Holmes, C. Schallenberg, P. Latour, M. Tonnard, M. J. A. Rijkenberg, D. Lannuzel, and A. R. Bowie, Talanta, 2019, 197, 653.

46. Y. Zhu, A. Hioki, and K. Chiba, J. Anal. At. Spectrom., 2013, 28, 883.

47. S. Kagaya, Y. Aoki, Y. Saeki, T. Goto, M. Ohki, I. Obata, M. Saito, R. Shirota, and M. Gemmei-Ide, Bull. Soc. Sea Water Sci., Jpn., 2017, 71, 282.

48. Y. Zhu, K. Nakano, Z. Wang, Y. Shikamori, K. Chiba, T. Kuroiwa, A. Hioki, and K. Inagaki, Anal. Sci., 2018, 34, 701.

49. Ministry of the Environment, Government of Japan, "Environmental Standards for Water Pollution", http:// www.env.go.jp/kijun/mizu.html. 